\title{
Differential response of antioxidant enzymes to cadmium stress in tol- erant and sensitive cell line of cucumber (Cucumis sativus L.)
}

\author{
Jarosław Gzyl ${ }^{\bowtie}$, Katarzyna Rymer and Edward A. Gwóźdź \\ Department of Plant Ecophysiology, Faculty of Biology, Adam Mickiewicz University, Poznań, Poland
}

Received: 15 June, 2009; revised: 05 October, 2009; accepted: 05 Decemeber, 2009

available on-line: 10 December, 2009

\begin{abstract}
Previously, a stable cell suspension of cucumber tolerant to $100 \mu \mathrm{M} \mathrm{CdCl}_{2}$ was obtained (Gzyl \& Gwóźdź, 2005, Plant Cell Tissue Organ Cult 80: 59-67). In this study, the relationship between the activity of antioxidant enzymes and cadmium tolerance of cucumber cells was analyzed. A cadmium-sensitive and the cadmium-tolerant cell lines were exposed to $100 \mu \mathrm{M}$ and $200 \mu \mathrm{M} \mathrm{CdCl}$ and the activities of superoxide dismutase (SOD), catalase (CAT), ascorbate peroxidase (APOX) and guaiacol peroxidase (POX) were determined. In the sensitive cell line, a decrease of total activity of SOD and POX was observed, whereas the activity of CAT and APOX significantly increased in metal-supplemented medium. By contrast, in the tolerant cells, the total activity of antioxidant enzymes decreased (SOD, CAT) or was maintained at approximately the same level (APOX, POX). Moreover, a different pattern of isoenzyme activity was observed in the tolerant and sensitive cells. These results suggest that an enhanced activity of antioxidant enzymes is not directly involved in the increased tolerance to cadmium of the selected cucumber cell line.
\end{abstract}

Keywords: cell suspension, cadmium, tolerance, superoxide dismutase, catalase, ascorbate peroxidase, guaiacol peroxidase

\section{INTRODUCTION}

It is well established that reactive oxygen species (ROS) are involved in the response of plants to biotic (Bolwell et al., 2002) and abiotic stresses (Gallego et al., 1996). The ROS include singlet oxygen $\left({ }^{1} \mathrm{O}_{2}\right)$, superoxide radical $\left(\mathrm{O}_{2}{ }^{--}\right)$, hydrogen peroxide $\left(\mathrm{H}_{2} \mathrm{O}_{2}\right)$ and hydroxyl radical $\left({ }^{\circ} \mathrm{OH}\right)$, which can trigger unrestricted oxidation of various cellular structures, leading to oxidative destruction of the cell (Mittler, 2002). Cadmium (Cd) toxicity also includes increased ROS generation (Olmos et al., 2003; Garnier et al., 2006), but the biochemical mechanism of ROS production during this metal stress is not completely elucidated. Cadmium does not participate in redox reactions and, in contrast to essential transition metals such as $\mathrm{Cu}$ and $\mathrm{Fe}$, it is unable to produce ROS through a Fenton-type reaction. Most studies indicate that an NADPH oxidase-like enzyme in the plasma membrane catalyzes the ROS production induced by Cd (Piqueras et al., 1999; Olmos et al., 2003). Also, cell wall peroxidases or polyamine oxidases have been suggested to contribute to $\mathrm{H}_{2} \mathrm{O}_{2}$ production (Apel \& Hirt, 2004). Regardless of the cadmium-induced mechanisms of ROS generation, their increased level is toxic and has to be controlled by a complex defense system. Antioxidant enzymes are primary components of the defense system and they are considered to play an important role in adaptation and survival of plants during periods of stress (Gallego et al., 2002; Singh et al., 2008). Previously, we selected a cell line of cucumber tolerant to cadmium which accumulates less phytochelatins (heavy metal binding peptides) than a sensitive one (Gzyl \& Gwóźdź, 2005). This suggests that phytochelatins are not directly responsible for the increased tolerance of cucumber cells and other mechanisms are probably associated with this phenomenon. Thus, in this paper we sought a correlation between tolerance to cadmium and activity of

${ }^{\square}$ Corresponding author: Jarosław Gzyl, Department of Plant Ecophysiology, Faculty of Biology, Adam Mickiewicz University, Umultowska 89, 61-614 Poznań, Poland; tel. (48) 61829 5812; fax: (48) 61829 5808; e-mail: jarekgzyl@yahoo.com Abbreviations: APOX, ascorbate peroxidase; CAT, catalase; POX, guaiacol peroxidase; ROS, reactive oxygen species; SOD, superoxide dismutase. 
antioxidant enzymes such as superoxide dismutase (SOD, EC 1.15.1.1), catalase (CAT, EC 1.11.1.6), guaiacol peroxidase (POX, EC 1.11.1.7) and ascorbate peroxidase (APOX, EC 1.11.1.11).

\section{MATERIALS AND METHODS}

Plant material and experimental conditions. The cell culture of cucumber (Cucumis sativus L. cv. Borszczagowski) was cultivated as described previously (Gzyl \& Gwóźdź, 2005). Cadmium was added to culture (MS medium) of sensitive and tolerant cells in $\log$ phase of growth for 2 days. The final concentration of cadmium in culture medium of both suspensions was $100 \mu \mathrm{M}$ or $200 \mu \mathrm{M} \mathrm{CdCl}_{2}$. After experiments, the cells were harvested on a sieve (Sigma, S-0770), frozen in liquid nitrogen and stored at $-80^{\circ} \mathrm{C}$ until analysis.

Protein extraction. The frozen cell samples were homogenized $(2: 1$ buffer volume:fresh mass) with a pestle and mortar in $100 \mathrm{mM}$ TRIS/ $\mathrm{HCl}, \mathrm{pH} 7.5$, on ice. For the APOX assay, proteins were extracted in $100 \mathrm{mM}$ sodium phosphate buffer ( $\mathrm{pH}$ 7.0) containing $5 \mathrm{mM}$ ascorbate and 1 $\mathrm{mM}$ EDTA. The homogenates were centrifuged for $15 \mathrm{~min}$ at $13800 \times \mathrm{g}\left(4^{\circ} \mathrm{C}\right)$. Protein concentration in the samples was estimated according to Bradford
(1976) using bovine serum albumin (BSA, Sigma) as a standard.

Enzyme activities. Samples of the extracts were separated in $10 \%$ (SOD, POX and APOX) or $8 \%$ (CAT) (w/v) polyacrylamide slab gels under nondenaturing conditions according to Davis (1964). Equal amounts of protein were loaded onto each lane for SOD, POX, APOX (50 $\mu \mathrm{g})$ and CAT $(12.5 \mu \mathrm{g})$ activity determinations. Isoenzymes of antioxidant enzymes were visualized in gels by the methods of Beauchamp and Fridovich (1971) for SOD, Woodbury et al. (1971) for CAT, Ros Barceló (1987) for POX and Mittler and Zilinskas (1993) for APOX. To semi-quantify the enzyme activities, stained gels were scanned and evaluated by ScanPack 3.0 software (Biometra). Computed values of cadmium-treated variants were expressed as percentages with respect to those of the control ones $(100 \%)$ scanned from the same electrophoretic separation. Relative activity diagrams represent data from three independent experiments and electrophoretic separations.

\section{RESULTS AND DISCUSSION}

Among the antioxidant enzymes, superoxide dismutase is a key enzyme in protecting cells against oxidative stress (Alscher et al., 2002). How-
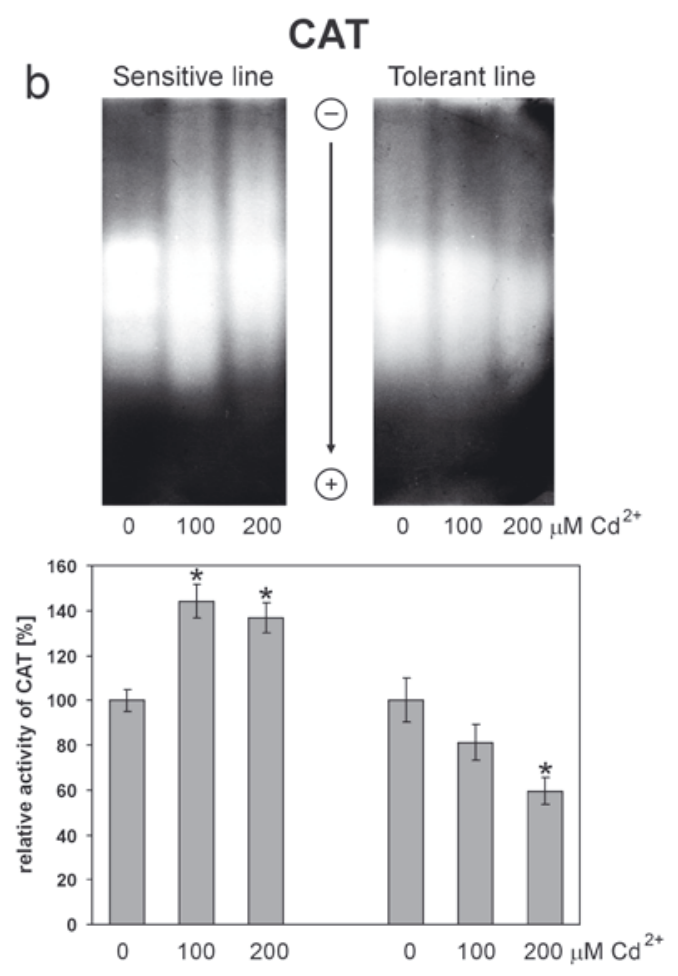

Figure 1. Isoenzyme pattern and activity of SOD (a) and CAT (b) in sensitive and tolerant cell lines of cucumber. Proteins were separated in non-denaturing polyacrylamide gel, the isoenzymes were visualized and evaluated as described in Materials and Methods. The cells of sensitive and tolerant lines were treated with $100 \mu \mathrm{M}$ or $200 \mu \mathrm{M} \mathrm{CdCl} 2$ for 2 days (cadmium was added in the log phase of suspension growth). Relative activity data are means \pm S.D. ( $n=3$ ). Asterisks indicate significant differences as compared to the control $(P<0.01)$. 
ever, in our work no relationship could be observed between the tolerance to cadmium and the activity of SOD. The total activity of this enzyme in the sensitive and tolerant cell lines decreased with increasing concentration of cadmium ions (Fig. 1a). A cadmium-induced reduction of SOD activity has also been observed in Phaseolus vulgaris (Somashekaraiah et al., 1992), sunflower leaves (Gallego et al., 1996), Amaranthus (Bhattacharjee, 1997), pea plants (Sandalio et al., 2001), and rice roots (Guo et al., 2007), and in those cases the activity of other antioxidant enzymes such as CAT, APOX or POX decreased as well. A different situation was observed in the cells of the sensitive line of cucumber. The decline of SOD activity was accompanied by a significant increase in the activity of $\mathrm{H}_{2} \mathrm{O}_{2}$-scavenging enzymes (Figs. 1b, 2a), the activity of APOX being stimulated much more than that of CAT, suggesting that this enzyme is a major player in $\mathrm{H}_{2} \mathrm{O}_{2}$ scavenging. The enhanced activity of $\mathrm{H}_{2} \mathrm{O}_{2}$-scavenging enzymes might be considered as evidence for Cd-induced $\mathrm{H}_{2} \mathrm{O}_{2}$ production and its involvement in the toxicity of cadmium to the sensitive cell culture. Thus, the inactivation of SOD observed in that line might be caused by an excess of $\mathrm{H}_{2} \mathrm{O}_{2}$ produced in different cell compartments as a result of $\mathrm{Cd}^{2+}$ toxicity (Scandalios, 1993; Sandalio et al., 2001). In fact, incubation of gels in $2 \mathrm{mM} \mathrm{KCN}$ and $3 \mathrm{mM} \mathrm{H}_{2} \mathrm{O}_{2}$ before stain-
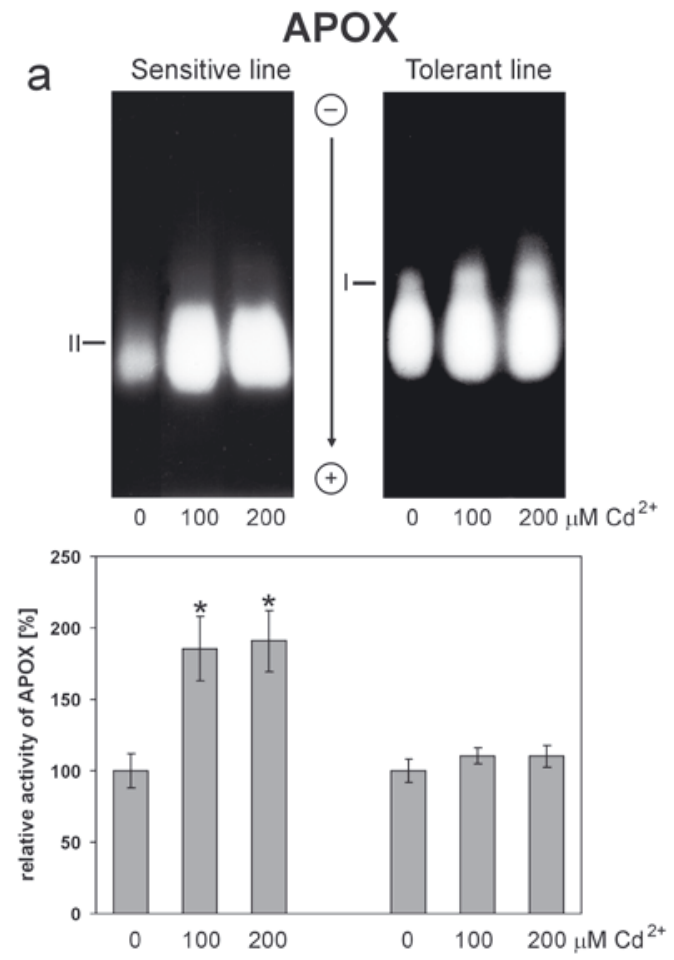

ing for SOD activity indicated that isoform I was identified as Mn-SOD, whereas isoforms II-V, the most affected by $\mathrm{Cd}^{2+}$, were classified as $\mathrm{H}_{2} \mathrm{O}_{2}$-sensitive isoenzymes of $\mathrm{Cu}, \mathrm{Zn}-\mathrm{SOD}$ (data not presented). Furthermore, the Cd-induced toxicity of $\mathrm{H}_{2} \mathrm{O}_{2}$ to the sensitive cells might be additionally enhanced by a lack of a dose-dependent increase in the activity of CAT and APOX (Figs. 1b, 2a). The activity of these enzymes was similar at $100 \mu \mathrm{M}$ and $200 \mu \mathrm{M} \mathrm{Cd}^{2+}$, suggesting that the capacity of the enzyme defense system had reached the maximum level and was sufficient to cope with the oxidative stress, but only for a relatively short-term exposition (2 days). It is consistent with the results of TTC (2,3,5-triphenyl tetrazolium chloride) reduction assays reported in our previous study (Gzyl \& Gwóźdź, 2005), where the sensitive cells cultured for 9 days in $100 \mu \mathrm{M}$ and $200 \mu \mathrm{M} \mathrm{CC^{2+ }}$ supplemented medium exhibited a dramatic reduction of viability (respectively 87 and $99 \%$ ). Therefore, a long-term exposure of the sensitive culture to the tested concentrations of cadmium rendered the cells unable to survive which could be related to enhanced generation of ROS that overwhelmed the antioxidant defense system and triggered a sequence of reactions leading to cell death.

Other tendencies were observed in the tolerant cell line subjected to the same cadmium concentration. Exposition to the metal ions decreased
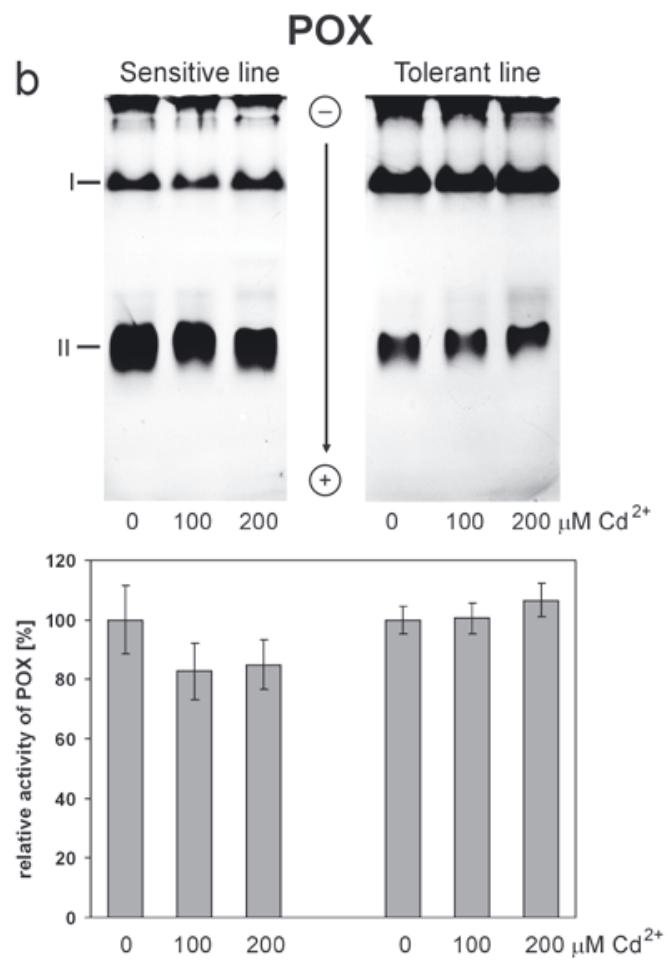

Figure 2. Isoenzyme pattern and activity of APOX (a) and POX (b) in sensitive and tolerant cell lines of cucumber. Proteins were separated in non-denaturing polyacrylamide gel, the isoenzymes were visualized and evaluated as described in Materials and Methods. The cells of sensitive and tolerant lines were treated with $100 \mu \mathrm{M}$ or $200 \mu \mathrm{M} \mathrm{CdCl} 2$ for 2 days (cadmium was added in the log phase of suspension growth). Relative activity data are means \pm S.D. ( $n=3$ ). Asterisks indicate significant differences as compared to the control $(P<0.01)$. 
the activity not only of SOD but also of CAT (Figs. $1 \mathrm{a}, \mathrm{b})$, with no significant changes in the total activity of APOX (Fig. 2a). So far, there is no ready explanation for the reduced activity of SOD and CAT, although down-regulation of their expression or post-translational modifications induced by cadmium cannot be excluded, as has been suggested by Romero-Puertas et al. (2007). Their transcriptome analysis of the antioxidative enzymes in leaves of pea plants adapted to long-term exposure to the metal has revealed the existence of a complex antioxidative response to $\mathrm{Cd}$ toxicity at the protein and gene levels. It has been suggested that $\mathrm{H}_{2} \mathrm{O}_{2}$ is involved in signal transduction pathways between the cadmium exposure and transcript expression of SOD and CAT (Romero-Puertas et al., 2007). Despite the inhibition of SOD and CAT activities, both the unchanged cell viability, checked by the TTC reduction assay (not shown), and ultrastructure analysis (Gzyl et al., 2009) indicate adaptation of the tolerant cells to cadmium. However, the level of APOX activity in the tolerant cells cultured without cadmium (control variant) was much higher than that in the sensitive line and an additional isoenzyme I was detected (Fig. 2a). This suggests that the APOX enzymes with their high affinity for $\mathrm{H}_{2} \mathrm{O}_{2}$ and ascorbate-glutathione cycle present in almost all plant cell compartments might act as a buffer to control the level of $\mathrm{H}_{2} \mathrm{O}_{2}$, shielding the tolerant cells from oxidative stress. Therefore, the essential nonenzymatic components like ascorbic acid and gluthatione might play a prominent role against $\mathrm{Cd}$ toxicity.

Differential response to cadmium was also observed in the POX isoenzymes' activity (Fig. 2b). The guaiacol peroxidases are widely accepted as stress enzymes and their activation has been reported under many stressful conditions, including cadmium exposure (Radotić et al., 2000; Sobkowiak et al., 2004). Although in our findings the total activity of POX decreased in the sensitive cells and did not change significantly in the tolerant ones upon cadmium exposure, the activity pattern of POX isoenzymes was clearly different. The sensitive cells exhibited high activity of isoform II, whereas the tolerant one had a more active isoform I (Fig. 2b). These results imply that not only the total activity of the enzyme but also its isoenzyme pattern might play an important role in stress conditions. Presented results demonstrated that in the cucumber culture there was no direct correlation between the tolerance to cadmium and the total activity of antioxidant enzymes. On the other hand, we cannot rule out an involvement of APOX and POX isoenzymes in the tolerance mechanisms. Our results imply that under $\mathrm{Cd}$ stress different defense strategies operate in the tolerant and sensitive lines of cucumber. In the sensitive line it relies on induction of common plant defense path- ways including high accumulation of phytochelatins (Gzyl \& Gwóźdź, 2005) and enhanced activity of at least some antioxidant enzymes (CAT, APOX), which together enable short-term survival of sensitive cells in cadmium-supplemented medium, whereas the tolerant cells seem to establish more complicated network of multiple response processes to control long-term $\mathrm{Cd}$ toxicity. Further research is needed to gain insight into these processes by which tolerant cucumber cells perceive cadmium toxicity and transmit it to the cellular machinery to activate an effective defense system.

\section{Acknowledgements}

We would like to thank Dr. R. Rucińska for technical support.

This research was supported by grant No. 6P04C 09112 from the State Committee for Scientific Research (Poland).

\section{REFERENCES}

Alscher RG, Erturk N, Heath LS (2002) Role of superoxide dismutases (SODs) in controlling oxidative stress in plants. J Exp Bot 53: 1331-1341.

Apel K, Hirt H (2004) Reactive oxygen species: Metabolism, oxidative stress, and signal transduction. Annu Rev Plant Biol 55: 373-399.

Beauchamp C, Fridovich I (1971) Superoxide dismutase: improved assays and an assay applicable acrylamide gels. Anal Biochem 44: 276-287.

Bhattacharjee S (1997) Membrane lipid peroxidation, free radical scavangers and ethylene evolution in Amaranthus as affected by lead and cadmium. Biol Plantarum 40: 131-135.

Bolwell GP, Bindschedler LV, Blee KA, Butt VS, Davies DR, Gardner SL, Gerrish C, Minibayeva F (2002) The apoplastic oxidative burst in response to biotic stress in plants: A three-component system. J Exp Bot 53: 1367-1376.

Bradford M (1976) A rapid and sensitive method for the quantitation of microgram quantities of protein utilising the principle of protein-dye binding. Anal Biochem 72: $248-254$.

Davis BJ (1964) Disc electrophoresis-II: method and application to human serum proteins. Ann $N$ Y Acad Sci USA 121: 404-427.

Gallego SM, Benavídes MP, Tomaro ML (1996) Effect of heavy metal ion excess on sunflower leaves: evidence for involvement of oxidative stress. Plant Sci 121: 151159.

Gallego SM, Benavídes MP, Tomaro ML (2002) Involvement of an antioxidant defence system in the adaptive response to heavy metal ions in Helianthus annuus L. cells. Plant Growth Regul 36: 267-273.

Garnier L, Simon-Plas F, Thuleau P, Agnel J-P, Blein J-P, Ranjeva R, Montillet J-L (2006) Cadmium affects tobacco cells by a series of three waves of reactive oxygen species that contribute to cytotoxicity. Plant Cell Environ 29: 1956-1969.

Guo B, Liang YC, Zhu YG, Zhao FJ (2007) Role of salicylic acid in alleviating oxidative damage in rice roots 
(Oryza sativa) subjected to cadmium stress. Environ Pollut 147: 743-749.

Gzyl J, Gwóźdź EA (2005) Selection in vitro and accumulation of phytochelatins in cadmium tolerant cell line of cucumber (Cucumis sativus). Plant Cell Tissue Organ Cult 80: 59-67.

Gzyl J, Przymusiński R, Gwóźdź EA (2009) Ultrastructure analysis of cadmium-tolerant and -sensitive cell lines of cucumber (Cucumis satious L.). Plant Cell Tissue Organ Cult 99: 227-232.

Mittler R (2002) Oxidative stress, antioxidants and stress tolerance. Trends Plant Sci 7: 405-410.

Mittler R, Zilinskas BA (1993) Detection of ascorbate peroxidase activity in native gels by inhibition of the ascorbate-dependent reduction of nitroblue tetrazolium. Anal Biochem 212: 540-546.

Olmos E, Martinez-Solano JR, Piqueras A, Hellín E (2003) Early steps in the oxidative burst induced by cadmium in cultured tobacco cells (BY-2 line). J Exp Bot 54: 291-301.

Piqueras A, Olmos E, Martinez-Solano JR, Hellín E (1999) Cd-induced oxidative burst in tobacco BY2 cells: time course, subcellular location and antioxidant response. Free Radical Res 31: 33-38.

Radotić K, Dučić T, Mutavdžić D (2000) Changes in peroxidase activity and isoenzymes in spruce needles after exposure to different concentrations of cadmium. Environ Exp Bot 44: 105-113.
Romero-Puertas MC, Corpas FJ, Rodriguez-Serrano M, Gómez M, del Río LA, Sandalio LM (2007) Differential expression and regulation of antioxidative enzymes by cadmium in pea plants. J Plant Physiol 164: 1346-1357.

Ros Barceló A (1987) Quantification of lupin peroxidase isoenzymes by densitometry. Ann Biol 14: 33-38.

Sandalio L, Dalurzo H, Gómez M, Romero-Puertas M, del Río L (2001) Cadmium-induced changes in the growth and oxidative metabolism of pea plants. J Exp Bot 52: 2115-2126.

Scandalios JG (1993) Oxygen stress and superoxide dismutases. Plant Physiol 101: 7-12.

Singh S, Anjum NA, Khan NA, Nazar R (2008) In Abiotic stress and plant responses. Khan NA, Singh S, ed, pp 165-196. I.K. International Publishing House Pvt. Ltd., New Delhi.

Sobkowiak R, Rymer K, Rucińska R, Deckert J (2004) Cadmium-induced changes in antioxidant enzymes in suspension culture of soybean cells. Acta Biochim Polon 51: 219-222.

Somashekaraiah BV, Padmaja K, Prasad ARK (1992) Phytotoxicity of cadmium ions on germinating seedlings of mung bean (Phaseolus vulgaris): involvement of lipid peroxides in chlorophyll degradation. Physiol Plant 85: 85-89.

Woodbury W, Spencer AK, Stahmann MA (1971) An improve procedure using ferricyanide for detecting catalase isoenzymes. Anal Biochem 44: 301-305. 